\title{
Expression of concern: Synthetic versions of firefly luciferase and Renilla luciferase reporter genes that resist transgene silencing in sugarcane
}

Jigisha Patel and Maria Kowalczuk*

\section{Expression of concern}

The publishers of this journal are publishing this Expression of Concern because attribution for the synthesis and design of the luc* and Renluc* coding sequences in this article [1] is under dispute.

The correct table and description of the method set out in Table S1 can be found in this article [2].

The University of Queensland advises that there has been no academic misconduct but the wording of any erratum remains under dispute.

Received: 1 December 2015 Accepted: 1 December 2015

Published online: 30 December 2015

\section{References}

1. Chou TC, Moyle RL. Synthetic versions of firefly luciferase and Renilla luciferase reporter genes that resist transgene silencing in sugarcane. BMC Plant Biol. 2014;14:92.

2. Jackson MA, Sternes PR, Mudge SR, Graham MW, Birch RG. Design rules for efficient transgene expression in plants. Plant Biotech J. 2014;12:925-33.

* Correspondence: Maria.Kowalczuk@biomedcentral.com This comment refers to the article available at: http://dx.doi.org/10.1186/ 1471-2229-14-92.

The authors of this Expression of Concern are members of The Research Integrity Group at BioMed Central. BioMed Central, 236 Gray's Inn Road, London WC1X 8HB, UK
Submit your next manuscript to BioMed Central and we will help you at every step:

- We accept pre-submission inquiries

- Our selector tool helps you to find the most relevant journal

- We provide round the clock customer support

- Convenient online submission

- Thorough peer review

- Inclusion in PubMed and all major indexing services

- Maximum visibility for your research

Submit your manuscript at

www.biomedcentral.com/submit

\section{() Biomed Central}

